\title{
Genotoxicity study of Ethiopian medicinal plant extracts on HepG2 cells
}

\author{
Wubayehu Kahaliw ${ }^{1 *}$, Bjorn Hellman ${ }^{2}$ and Ephrem Engidawork ${ }^{3}$
}

\begin{abstract}
Background: Most of herbal medicines are used without any standard safety and toxicological trials although common assumption is that these products are nontoxic. However, this assumption is incorrect and dangerous, so toxicological studies should be done for herbal drugs. Although Pterolobium stellatum, Otostegia integrifolia and Vernonia amygdalina root extracts are frequently used in Ethiopian traditional medicine, there are no evidences of their active toxic compounds. Therefore, we made an effort to assess probable genotoxic effect of these plant extracts on DNA of human hematoma $\left(\mathrm{HepG}_{2}\right)$ cells using alkaline comet assay.

Methods: Genotoxic effects of extracts were evaluated using single cell gel electrophoresis (SCGE) method on $\mathrm{HepG}_{2}$ cell. Regarding comet data, the average mean tail intensities (TI) from each individual experiment and treatment (usually at least 3 cultures/treatment) were pooled and the average mean TI was used as an indicator of DNA damage and the standard error of mean (SEM) as the measure of variance.

Results: DNA damage in the form of comet tail has been observed for 1 and $0.5 \mathrm{mg} / \mathrm{ml}$ P. stellatum chloroform and 80\% methanol extracts on $\mathrm{HepG}_{2}$ cells, respectively. The chloroform extract of $P$. stellatum showed increased tail DNA percentage in a concentration dependent manner. Comet tail length in the chloroform $P$. stellatum extract treated cells $(1 \mathrm{mg} / \mathrm{ml})$ was significantly higher by $89 \%(p<0.05)$ compared to vehicle treated controls. The rest of test extracts seemed to be without genotoxic effect up to a concentration of $0.5 \mathrm{mg} / \mathrm{ml}$.
\end{abstract}

Conclusions: Our findings show that two extracts from one plant evaluated have a genotoxic potential in vitro which calls for a more thorough safety evaluation. Such evaluation should include other end-points of genotoxicity apart from DNA damage, and possibly also pure compounds.

Keywords: Comet assay, Genotoxicity, Pterolobium stellatum, Otostegia integrifolia, Extracts

\section{Background}

Most of herbal medicines are used without any standard safety and toxicological trials although common assumption is that these products are nontoxic. However, this assumption is incorrect and dangerous, so toxicological studies should be done for herbal drugs. Although Pterolobium stellatum, Otostegia integrifolia and Vernonia amygdalina root extracts are frequently used, there are no evidences of their active toxic compounds. Therefore, we made an effort to assess probable genotoxic effect of these plant extracts on $\mathrm{HepG}_{2}$ cells using alkaline comet assay [1].

\footnotetext{
* Correspondence: wubayehu.kahaliw@uog.edu.et; kahaliw_w@yahoo.com; kahalil2003@gmail.com

${ }^{1}$ Department of Pharmacology, School of Pharmacy, College of Medicine and Health Sciences, University of Gondar, P. O. Box: 196, Gondar, Ethiopia
} Full list of author information is available at the end of the article
Pterolobium stellatum (Forsk.) Brenan. (Fabaceae) is also called kenteffa (Amharic). Pterolobium stellatum is a scrambling or climbing, rarely semi-erect, multi-stemmed shrub with recurved prickles, growing from 2 to $15 \mathrm{~m}$ tall. Pterolobium stellatum is widespread in Africa, where it is found from Sudan and Eritrea southwards throughout Central, East and southern Africa to South Africa, but not in Angola, Namibia and Botswana. It also occurs in Yemen [2]. Fresh leaves and roots are chewed for medicinal purposes for tuberculosis and related respiratory diseases, diarrhorea, epilepsy and neuralgia [3-5]. Boiled roots are also used to treat common colds, persistent cough (asthma), and spleenomegally [6].

Otostegia integrifolia Benth (Lamiaceae (Labiatae)), Tinjute (Amharic) is one of the plants used in Ethiopian traditional medicine [7]. The plant has insecticidal properties 
and is often used as fumigant for pots and houses [8]. Traditionally, it is used to treat diabetes mellitus, tonsillitis, uvulitis and hypertension, malaria, ascariasis and lung diseases [9-14]. There are more than 65 compounds that have been isolated from Otostegia. Particularly, compounds from O. integrifolia, O. perisca and O. fruticosa were pharmacologically important [15]. From the aerial parts of the plant, isolation of eight prefuranic and furanic labdane diterpenes together with iridoid glucoside was reported. These were otostegin A, otostegin B, 15-epi-otostegin $\mathrm{B}$, preleoheterin, leoheterin, and related compounds, including leopersin C, 15-epi-leopersin C, ballonigrin, vulgarol, and 8-O-acetylharpagide. In addition, the essential oil and chloroform extract of air-dried leaves of O. integrifolia were investigated and a total of 40 constituents including monoterpenes, sesquiterpenes, diterpenes and their derivatives were identified [16].

Vernonia amygdalina Del. (Asteraceae) has a variety of names in different languages. It is referred to as grawa (Amharic); vernonia tree, bitter leaf (English). Vernonia amygdalina is a shrub or small tree of $2-5 \mathrm{~m}$ with petiolate leaf of about $6 \mathrm{~mm}$ in diameter and elliptic shape. The leaves are green with a characteristic odor and bitter taste. The plant grows throughout Africa including Ethiopia. It is drought-resistant and thrives in humid environments $[17,18]$. It is used to treat tonsillitis, epidemic diseases, bacterial infections, cough, bleeding, gastrointestinal problems, tuberculosis, asthma, constipation, oxidative stress, helmintic infections, malarial infections, gastrointestinal disorders, loss of appetite, wounds, thrombi, diabetes mellitus, lipid disorders, and breast cancer [11, 19-31]. The methanol leaf extract was relatively safe with median lethal dose, $\mathrm{LD}_{50} \geq 5000 \mathrm{mg} / \mathrm{kg} /$ when single dose was administered orally to mice [32].

Phytochemical screening of $V$. amygdalina has revealed the presence of saponins, glycosides and tannins, which are known to be bioactive purgative principles. Flavonoids are also present in bitter leaf and have identified three flavones - luteolin, luteolin 7-O-beta-glucuronoside and luteolin 7-O-beta-glucoside. These flavones possess antioxidant activity and may play a beneficial role in cancer prevention and offer some protection against diabetes and atherosclerosis. The high content of the antioxidant vitamin $C$ present in $V$. amygdalina leaves also account for the antioxidant activity [33].

Drug discovery programs adopted cell-based assay applications with increasing frequency because cell systems are often inherently predictive of in vivo responses. Potential chemical toxicity, metabolic degradation or impaired permeability can be addressed with simple cell-based systems. Engineered or phenotype-specific lines also can be exploited to screen for compounds that modulate specific signaling cascades or regulatory elements [34].
Two types of variations in the genetic material of somatic cells which might lead to aging are DNA damage and mutations. DNA damages consist of a variety of chemical disorders in polynucleotide structure of the double helix, such as pyrimidine, apurinic sites, cross-links, and both large and small chemical additions, named adducts. DNA damage has a basic role in most of human diseases including cancer. An accurate, fast and sensitive method is required to evaluate DNA damage in toxicity studies, this method should be able to monitor DNA repair properly [1].

The aim of this work was to evaluate the genotoxic effects of $P$. stellatum chloroform and $80 \%$ methanol extracts as well as $O$. integrifolia and $V$. amygdalina chloroform extracts on $\mathrm{HepG}_{2}$ cells. Cells were treated with a range of extract concentrations from $0.01 \mathrm{mg} / \mathrm{ml}$ to $1 \mathrm{mg} / \mathrm{ml}$. Vehicle and catechol were used as negative and positive control respectively. The alkaline Comet assay was used to determine genotoxicity.

\section{Methods \\ Plant collection}

The roots of $O$. integrifolia, and $P$. stellatum were collected from an area near Angereb River, Gondar town, North West Ethiopia, about $730 \mathrm{~km}$ away from the capital, Addis Ababa. The root of $V$. amygdalina was collected from Bure town, North West Ethiopia, about $400 \mathrm{~km}$ far from Addis Ababa. The plants were authenticated by a taxonomist (Mr. Melaku Wondafrash) and a voucher specimen of each plant material was deposited at the National Herbarium, College of Natural and Computational Sciences, Addis Ababa University for future reference with voucher numbers Wk001, WK002 and WK004 for O. integrifolia, P. stellatum and $V$. amygdalina, respectively. The plants were cleaned from dirt and soil and dried under shade for 2 weeks. The plants were spread out and regularly turned over to avoid fermenting and rotting. The dried root parts of plants were grinded using $0.75 \mathrm{~mm}$ sieve size hammer type mill, while the dried leaves were pulverized using a wooden mortar and pestle. The powdered material was weighed using an analytical balance and stored at room temperature.

\section{Crude extract}

The air-dried; powdered roots of P. stellatum, O. integrifolia and $V$. amygdalina were exhaustively extracted with chloroform using maceration technique. Maceration was carried out using one liter of the respective solvent for $72 \mathrm{~h}$, with regular shaking. The mixture was filtered with whatman No. 42 filter paper (Whatman No.42, England) and the filtrate was kept at $+4^{\mathrm{O}} \mathrm{c}$. The marc was macerated again in the same solvent two times and filtered. The filtrates were combined evaporated under reduced pressure on a rotary 
evaporator (Buchi Rota Vapor R-200) and dried in oven at $40^{\circ} \mathrm{C}$ (Gallenkamp, England).

In parallel, the air-dried and powdered roots of $P$. stellatum were soxhlet extracted with $80 \%$ methanol (4:1, methanol: water). The extracts were filtered and evaporated under reduced pressure on a rotary evaporator and lyophilized. The extracts were kept refrigerated and away from light.

\section{Selection of exposure concentrations}

Before the main experiments, pilot studies of solubility and viability were done to find the appropriate exposure concentrations for the evaluation of DNA damage (data not shown). The solubility of the extracts was tested in different solvents using $0.5 \mathrm{mg} / \mathrm{ml}$ as the maximum concentration during exposure. P. stellatum chloroform and $80 \%$ methanol extracts were easily soluble in $99.5 \%$ ethanol where as $O$. integrifolia and $V$. amygdalina chloroform, extracts were soluble in DMSO at $50 \mathrm{mg} / \mathrm{ml}$. The final concentration of vehicle (solvent) was non-toxic and did not exceed 1\%. The viability of the cells after $3 \mathrm{~h}$ exposure was checked using the Trypan blue exclusion method. According to Tice et al. [35], cell viability below $70 \%$ is considered to indicate cytotoxicity and lower cell viability than that should be avoided when evaluating potential genotoxicity in the comet assay. Thus, 0.01 to $1 \mathrm{mg} / \mathrm{ml}$ concentrations were used.

\section{Cell culture and exposure}

Evaluation of genotoxic effects of crude extracts were carried out using $\mathrm{HepG}_{2}$ cells. Cells were obtained from department of pharmaceutical biosciences, faculty of pharmacy, Uppsala University, Sweden. Cryo preserved cells were cultured in Dulbecco's Modified Eagle's Medium (DMEM) containing 10\% fetal calf serum (FCS) and $1 \%$ pencillin-streptomycin. One $\mathrm{T}_{75}$ flask containing $1 \times 10^{6}$ cells and two $\mathrm{T}_{25}$ flasks containing $3 \times 10^{5}$ cells were incubated for 3 days under $5 \% \mathrm{CO}_{2}$ at $37^{\circ} \mathrm{C}$. After 3 days, the cell culture was washed with phosphate buffer saline (PBS) and warmed at $37^{\circ} \mathrm{c}$. Then, $2 \mathrm{ml}$ and $1 \mathrm{ml}$ trypsin was added to $\mathrm{T}_{25}$ and $\mathrm{T}_{75}$ culture flasks, respectively, incubated under $5 \% \mathrm{CO}_{2}$ for $5 \mathrm{~min}$. Fresh medium was added to the flasks and pooled in to a falcon tube. Then, the combined culture was centrifuged at $1100 \mathrm{rpm}$ for $5 \mathrm{~min}$ and the pellet re-suspended with $3 \mathrm{ml}$ media. After determining cell count, $4 \times 10^{5}$ cells were seeded to six well plates in triplicate and incubated under $5 \% \mathrm{CO}_{2}$ at $37^{\circ} \mathrm{c}$ for 2 days.

After 2 days of incubation, the medium was thrown away, washed twice with PBS and the cells were treated with the extract. Extract treated and control cultures were incubated for $3 \mathrm{~h}$ under $5 \% \mathrm{CO}_{2}$ at $37^{\circ} \mathrm{C}$. After $3 \mathrm{~h}$, the medium was thrown away, trypsin was added and neutralized. Neutralized culture was centrifuged in five different falcon tubes and $1 \mathrm{ml}$ of medium was added to each falcon to use for next stages of the comet assay.

\section{Comet assay}

Immediately after exposure and washing, the cells were put on ice until the slides for the comet assay were ready and the cell viability was determined using the trypan blue technique. Only cell suspensions with viabilities of more than $90 \%$ were used for determination of DNA damage.

Each experimental set up was based on three independent electrophoresis runs, and from each electrophoresis run (cell culture); three slides per treatment were prepared for the assay. The DNA damage was evaluated using the alkaline version of the comet assay following a slightly modified protocol of Tice et al. [35] and Singh et al. [36]. Immediately after cell viability determination, the cells were centrifuged twice with DMEM, 5\% FCS and 1\% pencillin-streptomycin. The cells were then re-suspended and mixed with low melting point agarose at $37^{\circ} \mathrm{C}$ and applied to microscope slides (Menzel-Gläser Diagnostika, Germany), which had been pre-coated with normal melting point agarose. Triplicate slides were applied for each extract and control. The slides were covered with cover slip and placed in cold plate for $15 \mathrm{~min}$ at $4^{\circ} \mathrm{c}$. The slides were then uncovered and incubated in a lysis buffer (2.5 M NaCl, $100 \mathrm{mM}$ ethylenediamine tetraacetic acid (EDTA), $10 \mathrm{mM}$ Trizma base, 1\% Triton X-100, 10\% DMSO, pH 10 adjusted with $\mathrm{NaOH}$ ) at $4^{\circ} \mathrm{c}$ for $1 \mathrm{~h}$ protected from light.

The slides were transferred to an electrophoresis chamber at $4^{\circ} \mathrm{C}$ where they were treated in the dark with an alkaline electrophoresis buffer (300 mM NaOH, $1 \mathrm{mM}$ EDTA, $\mathrm{pH}>13$ ) for $40 \mathrm{~min}$ before subjected to electrophoresis (25 V and $300 \mathrm{~mA}$ ) in darkness at $4^{\circ} \mathrm{C}$ for $10 \mathrm{~min}$. After electrophoresis, the slides were washed for $15 \mathrm{~min}$ in a buffer $(0.4 \%$ Tris, $\mathrm{pH} 7.5)$, dried and stored in closed containers until the day of image analysis.

GelRed was added $(10 \mu \mathrm{l})$ to $50 \mathrm{ml}$ distilled water in a cuvette and the slides were incubated in the cuvette for $30 \mathrm{~min}$ in dark. The slides were held in neutralization solution ( $\mathrm{pH} 7.5$ ) for $30 \mathrm{~s}$ in dark. The slides were then kept in a humidity chamber until detection. After staining of the slides, detection was performed with an Olympus BX60 fluorescence microscope with an AVT FireWire camera (Stingray; Allied Technologies, Germany), a CoolLED pE-100 excitation light $(536 \mathrm{~nm})$ and the software Comet Assay IV (Perspective instruments, UK). All slides were coded independently and scored blindly. Apparently dead cells (comets without distinct heads: "clouds") and super imposed comets were not captured during the image analysis. Fifty cells per slide were examined. All tests and controls were used in triplicate and at least three experiments were performed, 
which gave 450 examined cells per treatment. The mean tail intensity (showing the percentage of DNA that had moved from the nucleus towards the anode during electrophoresis) was used as an indicator for the level of DNA damage. Relative fluorescence intensity of head and tail, normally expressed as a percentage of DNA in the tail was considered as the parameter for measuring DNA damage in this case. This parameter is linearly related to the break frequency and covers the widest range of damage [37].

\section{Statistical evaluation of data}

The statistical analysis of all results was done using the Statistica 10 and GraphPad Prism 5 softwares and the level of statistical significance was set at $P<0.05$. Regarding comet data, the average mean tail intensities from each individual experiment and treatment (usually at least 3 cultures/treatment) were pooled and the average mean tail intensity was used as an indicator of DNA damage and the SEM as the measure of variance.

Differences in average values between vehicle-treated control cells and extract-exposed $\mathrm{HepG}_{2}$ cells were evaluated using a two-tailed unpaired t-test for independent samples, assuming equal variance between the different average mean values.

\section{Results}

White spots were detected in the genotoxicity assay of selected plant extracts as shown in Fig. 1. Comets with distinct heads and without tails (Fig. 1a) were vehicle treated non- migrated nuclear DNA from individual cells, whereas comets with distinct heads and tails (Fig. 1b) were extract treated and migrated ones.

Percent DNA in tail (tail intensity) in the DNA damage evaluation of the extracts along with the test concentrations are presented in Table 1. DNA damage in the form of comet tail was observed on $\mathrm{HepG}_{2}$ cells exposed to 1 and $0.5 \mathrm{mg} / \mathrm{ml}$ of $P$. stellatum chloroform and $80 \%$ methanol extracts (Table 1), respectively. The tail DNA percent ranged from $2.00 \pm 0.09$ to $4.03 \pm 0.57$ for $P$. stellatum chloroform extract treated sets at a concentration range of 0.01 to $1 \mathrm{mg} / \mathrm{ml}$. The range was $2.61 \pm 0.14$ to $2.95 \pm 0.02$, $2.16 \pm 0.26$ to $3.02 \pm 0.24$, and $1.73 \pm 0.10$ to $2.90 \pm 0.18$ at test concentrations of 0.01 to $0.5 \mathrm{mg} / \mathrm{ml}$ for the chloroform extract of $O$. integrifolia, and for the chloroform extract of $V$. amygdalina (Table 1), respectively.

The chloroform extract of $P$. stellatum showed increased tail DNA percentage in a concentration dependent manner. It had an increased genotoxic effect after $3 \mathrm{~h}$ exposure at a concentration of $1 \mathrm{mg} / \mathrm{ml}$ compared to controls. Comet tail length in the extract treated cells $(1 \mathrm{mg} / \mathrm{ml})$ was significantly higher by $89 \%(p<0.05)$ compared to vehicle treated controls. However, at lower concentrations no apparent genotoxic effect was observed. The extent of DNA damage at $1 \mathrm{mg} / \mathrm{ml}$ exposure was comparable to the damage induced by the positive control (3 $\mathrm{mM}$ catechol) (Fig. 2).

Pterolobium stellatum 80\% methanol extract significantly increased DNA damage at a concentration of $0.5 \mathrm{mg} / \mathrm{ml}$ $(p<0.001)$ when compared to the vehicle treated cells, although the damage was not concentration dependent (Fig. 2). Concentrations lower than $0.5 \mathrm{mg} / \mathrm{ml}$ were not significantly associated with DNA damage.

Treatment of cells with the choloroform extract of O. integrifolia did not show any detectable DNA damage at all exposure concentrations as compared to vehicle treated controls. However, the positive control demonstrated significant damage $(p<0.05)$ (Fig. 3).

Treatment of $\mathrm{HepG}_{2}$ cells with $V$. amygdalina at $0.01,0.05$ and $0.25 \mathrm{mg} / \mathrm{ml}$ concentrations showed tail DNA percentages $1.73 \pm 0.10,1.54 \pm 0.17$ and $2.15 \pm$ 0.24 respectively. The values were lower than the tail DNA percentage of the negative control $(2.62 \pm 0.01)$, while the value $(2.90 \pm 0.18)$ at $0.5 \mathrm{mg} / \mathrm{ml}$ exposure was greater than the negative control. Treatment of $\mathrm{HepG}_{2}$ cells with the chloroform extract of $V$. amygdalina produced a significant decrease in percentage DNA in tail at $0.01 \mathrm{mg} / \mathrm{ml}(p<0.001)$ and $0.05 \mathrm{mg} / \mathrm{ml}(p<0.05)$ compared to negative controls. The decrease and increase observed at $0.25 \mathrm{mg} / \mathrm{ml}$ and $0.5 \mathrm{mg} / \mathrm{ml}$, respectively, however, was not statistically significant (Fig. 3).

\section{Discussion}

The persistent use of traditional medicine in African population and natural products growing use in developed countries has led to a resurgence of the scientific
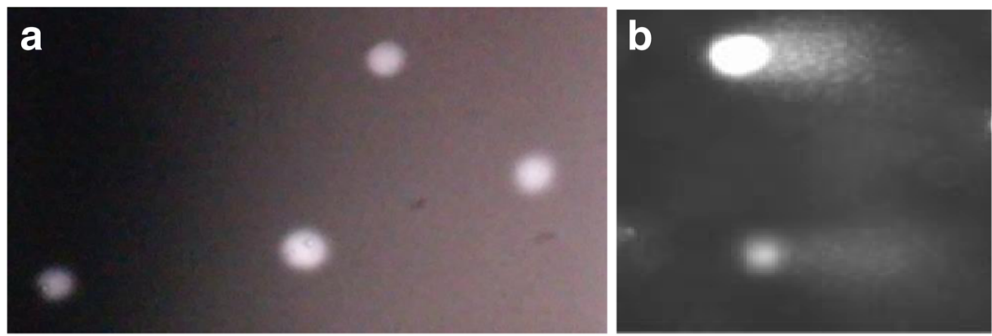

Fig. 1 White spots [(a) comets without tails (b) comets with tails] of the comets that were detected in genotoxicity test. The software Comet Assay IV (Perspective instruments, UK) was used to analyse the images 


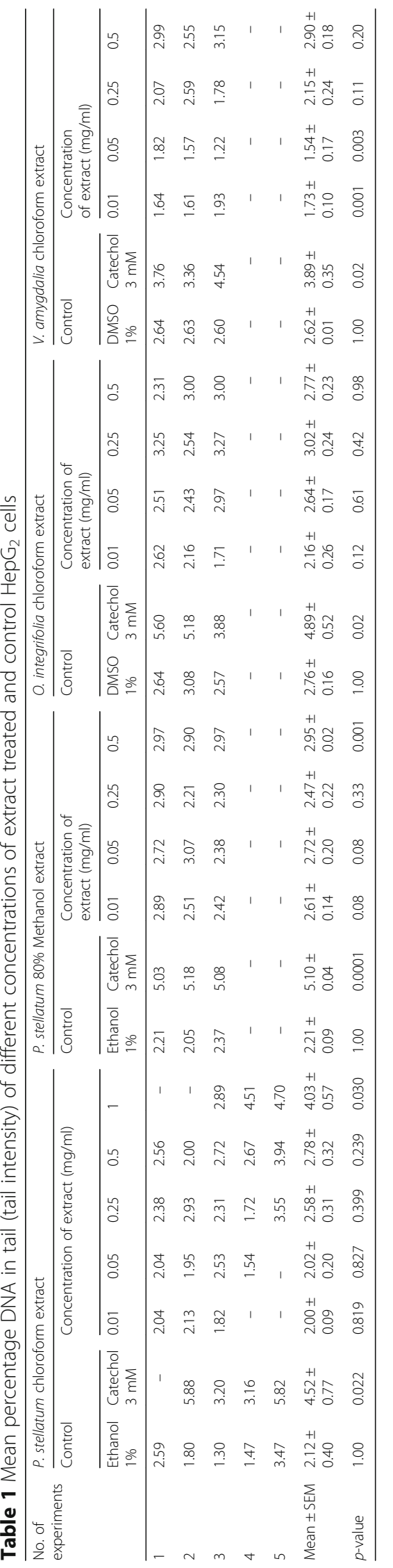




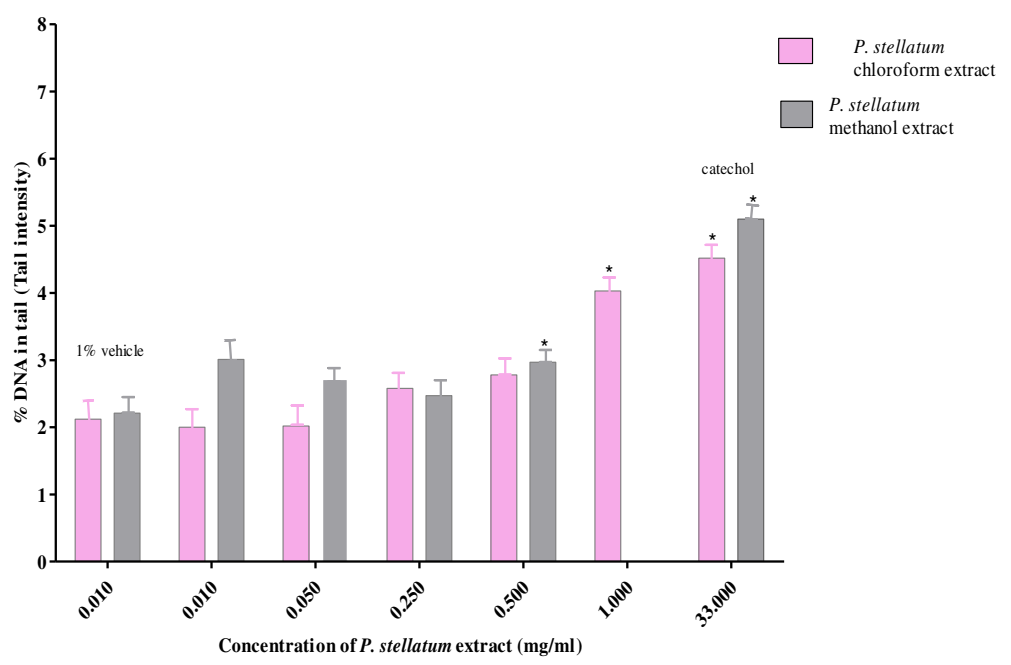

Fig. 2 Genotoxic effect of Ptrolobium stellatum extracts on $\mathrm{HepG}_{2}$ cells: cells were exposed for $3 \mathrm{~h}$ and DNA damage was monitored as an increase in percentage of DNA in the tail (tail intensity) after $10 \mathrm{~min}$ of electrophoresis in the comet assay. \% vehicle $=1 \%$ ethanol (negative control) and $3 \mathrm{mM}$ catechol (positive control). The means of percentage of DNA in tail for at list three experiments were compared with the vehicle control using T-test for independent samples

interest in their biological effects. The assessment of the efficacy and safety profiles of the medicinal plants should be based on scientific evidence-based approaches including the genotoxic profile of such plants. The short-term tests for genotoxicity are typically used to identify potential mutagens and carcinogens. According to the frequent use of P. stellatum, O. integrifolia and V. amygdalina and no evidences of their active toxic compounds, we made an effort to assess probable effect these plants' extracts on DNA of hep $G_{2}$ cells using the alkaline comet assay [1].

Direct interaction between a DNA-reactive agent and DNA is one of several pathways that may lead to primary DNA damage in which the major end-points such as DNA strand breaks (which could also reflect repair incisions) and alkali labile sites are measured in the comet assay [38]. The comet assay has expanded an internationally wellknown method to assay DNA damage in various cell types during the last three decades. It is believed that the comet assay is still growing in use and has high potential to be used in clinical and cancer research [1].

Major constituents have been identified in extracts from O. integrifolia and $V$. amygdalina, but the potential genotoxicity of these constituents remains rather obscure. However, there is sparse data regarding the bioactivity, safety and major constituents of $P$. stellatum. It is therefore difficult to assume that genotoxic effect observed at $1 \mathrm{mg} / \mathrm{ml}$ chloroform and $0.5 \mathrm{mg} / \mathrm{ml} 80 \%$ methanol extracts of $P$. stellatum might be induced by

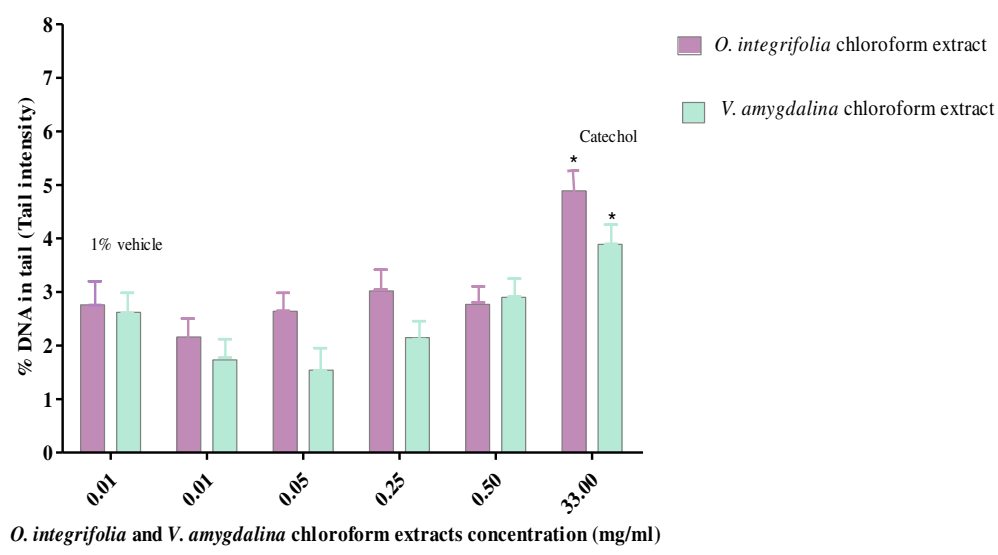

Fig. 3 Genotoxic effect of Otostegia integrifolia and $V$. amygdalina chloroform extracts on HepG $\mathrm{H}_{2}$ cells: cells were exposed for $3 \mathrm{~h}$ and DNA damage was monitored as an increase in percentage of DNA in the tail (tail intensity) after $10 \mathrm{~min}$ of electrophoresis in the comet assay. \% vehicle $=1 \%$ DMSO (negative control) and $3 \mathrm{mM}$ catechol (positive control). The means of percentage of DNA in tail for at list three experiments were compared with the vehicle control using T-test for independent samples 
a specific compound. At the antimycobacterial concentration $(0.039 \mathrm{mg} / \mathrm{ml})$, these extracts were without DNA damaging effect [39].

This in vitro study was done on HepG2 cell culture and there is a long way to extrapolate to in vivo and determine the amount of plant that would affect human hepatoma. It is important to perform an in vivo study to recognize the amount of the plant that should be consumed orally to create concentrations of the herb extract that is genotoxic for HepG2 cells. In addition in vivo study helps to conclude if the amount of herb which is normally consumed is equal to amount of herb that is needed to make genotoxic effect and on the basis of this case decide about that normal use are genotoxic or not. In our previous study [39], the oral $\mathrm{LD}_{50}$ was greater than $5000 \mathrm{mg} / \mathrm{kg}$ for P. stellatum chloroform extract. However, sub-chronic and chronic toxicity as well as in vivo genotoxicity should be evaluated to establish the range of concentrations for the safe use of this plant extract.

In previous studies the aqueous and hydro-alcoholic extracts of $E$. amoenum increased \% DNA in tail significantly and concentration dependently indicating the genotoxicity of these plants and their capability of DNA damage which is comparable with our finding in P. stellatum chloroform extract. However, the chloroform root extract of $P$. stellatum in this study was more genotoxic than the aqueous and hydro-alcoholic extracts of $N$. jatamansi and aqueous extract of E. amoenu [1].

Methanolic extract of $P$. stellatum showed significant increase in percentage DNA in tail at $0.5 \mathrm{mg} / \mathrm{ml}$ and this concentration was less than that shown by chloroform extract. It is therefore fair to assume that the methanolic extract of this plant might contain higher amounts of genotoxic constituents than the chloroform extract. In addition, $O$. integrifolia and $V$. amygdalina chloroform extracts were without significant genotoxic effects at the test concentrations. Conversely, research has indicated that one of the chemical constituents of O. integrifolia called stigmasterol had anti-genotoxic effect. Therefore it may be useful in prevention of certain cancers, including ovarian, prostate, breast, and colon cancers [14].

Upon exposure of $\mathrm{HepG}_{2}$ cells to $V$. amygdalina chloroform extract, significant increase in percentage DNA in tail was not induced and hence the extract didn't show genotoxic effect at all test concentrations. The percent DNA in tail decrease at and below $0.05 \mathrm{mg} / \mathrm{ml}$ may be attributed to the extract's action to protect the cells from background damage at low concentrations. In the previous study [31], the leaf extract of $V$. amygdalina indicated dose-dependent increase in DNA damage, reaching statistically significant value at $2 \mathrm{mg} / \mathrm{ml}$ in MCF-7 cells. Therefore, the DNA damaging effect of the root extract of $V$. amygdalina in this study is in agreement with study done on its leaf extract.
The major constituents in the leaves of $V$. amygdalina are different types of saponins and various flavonoids such as luteolin, luteolin 7-O-beta-glucuronoside, luteolin 7-O-beta-glucoside and vitamin $\mathrm{C}$. These flavones possess antioxidant activity and might play a beneficial role in protection against background DNA damage which was observed at 0.01 and $0.05 \mathrm{mg} / \mathrm{ml}$ exposure [33]. The dose dependent genotoxic effect (though not statistically significant) at test concentrations equal/higher than $0.25 \mathrm{mg} / \mathrm{ml}$ might be attributable to higher concentrations of saponins and/or pro-oxidant flavonoids in this extract [38].

\section{Conclusion}

The present paper has shown that chloroform and 80\% methanol extracts of $P$. stellatum induced significant DNA damage in HepG2 cells. This suggests that components in these extracts might interact directly with the DNA. Studies with crude extracts are appropriate because it is in this form they are used as traditional herbal medicines. Some of the constituents in such plants can be genotoxic, others can be anti-genotoxic. Our findings show that two extracts from one plant evaluated have a genotoxic potential in vitro which calls for a more thorough safety evaluation. Such evaluation should include other end-points of genotoxicity apart from DNA damage, and possibly also pure compounds.

\section{Abbreviations \\ ANOVA: Analysis of Variance; DMEM: Dulbecco's Modified Eagle's Medium; DMSO: Dimethylsulphoxide; DNA: Deoxyribonucleic Acid; EDTA: Ethylenediamine Tetraacetic Acid; FCS: Fetal Calf Serum; \\ $\mathrm{HepG}_{2}$ : Human Hepatoma Cells; PBS: Phosphate Buffer Saline; SCGE: Single Cell Gel Electrophoresis; SD: Standard Deviation; SEM: Standard Error Of Mean; TI: Tail Intensities}

\section{Acknowledgements}

The authors are thankful to Addis Ababa University, University of Gondar and Armauer Hanson Research Institute for funding the study. We are also grateful to Department of Pharmaceutical Biosciences, Division of Toxicology, Uppsala University, Uppsala, Sweden for providing lab space and consumables.

\section{Funding}

The sources of funding for this research are as follows:

The source of fund for the design of the study, plant sample collection and my doctoral research visit stay in Sweden was Addis Ababa University where as Department of Pharmaceutical Biosciences, Division of Toxicology; Uppsala University, Sweden provided lab space and consumables. Analysis and interpretation data and manuscript writing was funded by University of Gondar.

\section{Availability of data and materials}

Almost all the materials and data of our study are included in the manuscript, a few of the material and data will be available to other researchers upon request.

\section{Authors' contributions}

All authors have made substantial contributions in the research, preparation and revision of manuscript. The principal contributor for the conception and design, acquisition, analysis and interpretation of data as well as manuscript writing was WK. EE and $\mathrm{BH}$ involved in the design of the study, revising the manuscript critically for important intellectual content. Each author has participated in the work and has given final approval of the version to be published. 


\section{Ethics approval and consent to participate}

Not applicable.

\section{Consent for publication}

Not applicable.

\section{Competing interests}

The authors declare that they have no competing interests.

\section{Publisher's Note}

Springer Nature remains neutral with regard to jurisdictional claims in published maps and institutional affiliations.

\section{Author details}

'Department of Pharmacology, School of Pharmacy, College of Medicine and Health Sciences, University of Gondar, P. O. Box: 196, Gondar, Ethiopia. ${ }^{2}$ Department of Pharmaceutical Biosciences, Division of Toxicology, Uppsala University, Box 594, 75124 Uppsala, Sweden. ${ }^{3}$ Department of Pharmacology and Clinical Pharmacy, School of Pharmacy, College of Health Sciences, Addis Ababa University, P. O. Box: 1176, Addis Ababa, Ethiopia.

Received: 18 May 2017 Accepted: 11 December 2017

Published online: 01 February 2018

\section{References}

1. Etebari M, Zolfaghari B, Jafarian-Dehkordi A, Rakian R. Evaluation of DNA damage of hydro-alcoholic and aqueous extract of Echium amoenum and Nardostachys jatamansi. J Res Med Sci. 2012;17:782-6.

2. Jansen PCM. Pterolobium stellatum (Forssk.) Brenan. In: Jansen PCM, Cardon D, editors. PROTA (plant resources of tropical Africa / Ressources végétales de l'Afrique tropicale). Wageningen; 2005. [Internet] Record from PROTA4U. http://www.prota4u.org/search.asp. Accessed 11 Aug 2017

3. Andualem G, Umar S, Getnet F, Tekewe A, Alemayehu H, Kebede N Antimicrobial and phytochemical screening of methanol extracts of three medicinal plants in Ethiopia. Advan Biol Res. 2014;8(3):101-6.

4. Balcha E, Mengiste B, Gebrelibanos M, Worku A, Ameni G. Evaluation of in-vitro antimycobacterial activity of selected medicinal plants in Mekelle, Ethiopia. World Appl Sci J. 2014;31(6):1217-20

5. Flatie T, Gedif T, Asres K, Gebre-Mariam T. Ethnomedical survey of Berta ethnic group Assosa zone, Benishangul-Gumuz regional state, mid-West Ethiopia. J Ethnobiol Ethnomed. 2009:5:14

6. Kigen G, Maritim A, Some F, Kibosia J, Rono H, Chepkwony S, Kipkore W, Wanjoh B. Ethnopharmacological survey of the medicinal plants used in tindiret, nandi county, Kenya. Afr J Tradit Complement Altern Med. 2016;13(3):156-68.

7. Mohammed S, Abraha B. Floristic composition and structure of Yegof Mountain Forest, south Wollo, Ethiopia. Eth J Sci Technol. 2013;6(1):33-45.

8. Kidane D, Tomass Z, Dejene T. Community knowledge of traditional mosquito repellent plants in Kolla Temben District, Tigray, northern Ethiopia. Sci Res Essays. 2013;8(24):1139-44

9. Meresa A, Gemechu W, Basha H, Fekadu N, Teka F, Ashebir R, Tadele A. Herbal medicines for the management of diabetic mellitus in Ethiopia and Eretria including their phytochemical constituents. AJADD. 2017;5(01):040-58.

10. Andemariam SW. Legislative regulation of traditional medicinal knowledge in Eritrea vis-a-vis Eritrea's commitments under the convention on biological diversity: issues and alternatives. Env Dev J. 2010;6:130.

11. Giday M, Teklehaymanot T, Animut A, Mekonnen Y. Medicinal plants of the Shinasha, Agew-awi and Amhara peoples in north West Ethiopia. J Ethnopharmacol. 2007;110:516-25.

12. Parvaz N, Yadav S. Ethno pharmacology of single herbal preparations of medicinal plants in Asendabo district, Jimma, Ethiopia. Ind J Trad Know. 2010;9:724-9.

13. Endale A, Bisrat D, Animut A, Bucar F, Asres K. In vivo Antimalarial activity of a labdane diterpenoid from the leaves of Otostegia integrifolia Benth. Phytother Res. 2013;27:1805-9.

14. Karunamoorthi K. Tinjute [Labiatae; (Otostegia integrifolia)]: a versatile Ethiopian ethnomedicinal plant-a systematic review of the scientific evidences. Tang [Humanitas Medicine]. 2014;4(2):8.

15. Khan S, Syed F. Bioactive constituents from genus Otostegia. SARJ of Physical Sci. 2013;1:15-25.

16. Tesso H, König A. Terpenes from Otostegia integrifolia. Phytochemistry. 2004; 65:2057-62
17. Eyo JE, Nwachukwu LO, Onah IE, Atama Cl, Ekeh FN, Ezenwaji NE, Ivoke N Effects of the aqueous root extract of Vernonia amygdalina on the haematological profile of Rattus Norvegicus. Adv Life Sci Technol. 2013;11:19-24.

18. Offor CE. A comparative chemical analyses of Vernonia amygdalina and Azadirachta indica leaves. IOSR-JPBS. 2014;9(5):73-7.

19. Uzodimma DE. Medico-Ethnobotanical inventory of Ogii, Okigwe Imo state, south eastern Nigeria. Glo Adv Res J Med Plants. 2013;2(2):030-44.

20. Ghamba PE, Balla H, Goje LJ, Halidu A, Dauda MD. In vitro antimicrobial activities of Vernonia amygdalina on selected clinical isolates. Int J Curr Microbiol App Sci. 2014;3(4):1103-13.

21. Egharevba C, Osayemwenre E, Imieje V, Ahomafor J, Akunyuli C, Udu-Cosi AA, Theophilus O, James O, Ali I, Falodun A. Significance of bitter leaf (Vernonia amagdalina) in tropical diseases and beyond: a review. Malar Chemoth Cont. 2014;3:1.

22. Sirama V, Kokwaro J, Owuor B, Yusuf A, Kodhiambo M. In-vitro anthelmintic activity of Vernonia amygdalina Del. (asteraceae) roots using adult Haemonchus contortus worms. Int J Pharmacol Res. 2015:5(1):1-2

23. Abdrazak M, Afzan A, Ali R, Jalaluddin N, Wasiman M, Zahari S, Abdullah N, Ismail Z. Effect of selected local medicinal plants on the asexual blood stage of chloroquine resistant Plasmodium falciparum. BMC Complement Altern Med. 2014;14:492.

24. Bunalema L, Obakiro S, Tabuti JRS, Waako P. Knowledge on plants used traditionally in the treatment of tuberculosis in Uganda. J Ethnopharmacol. 2014:151:999-1004

25. Makinde SCO, Ojekale AB, Oshinaike TS, Awusinu TS. An ethnomedical and ethnobotanical survey of plants herbal therapy used for obesity, asthma, diabetes and fertility by the Badagry people of Lagos state, Nigeria. J Med Plants Studies. 2015;3(5):01-6.

26. Adedapo AA, Aremu OJ, Oyagbemi AA. Anti-oxidant, anti-inflammatory and antinociceptive properties of the acetone leaf extract of Vernonia Aamygdalina in some laboratory animals. Adv Pharm Bull. 2014;4(2):591-8.

27. Nalule AS, Mbaria JM, Kimenju JW. In vitro anthelmintic potential of Vernonia amygdalina and Secamone africana on gastrointestinal nematodes. Agric Biol J N Am. 2013;4(1):54-66

28. Adebayo OL, James A, Kasim SB, Jagri OP. Leaf extracts of Vernonia amygdalina Del. From northern Ghana contain bioactive agents that inhibit the growth of some beta-lactamase producing bacteria in vitro. Br J Pharm Res. 2014;4(2):192-202.

29. Oyedeji KO, Bolarinwa AF, Akintola AM. Effect of methanolic extract of Vernonia amygdalina on haematological and plasma biochemical parameters in male albino rats. IOSR J Dental Med Sci. 2013;3(5):64-7.

30. Kennedy IC, Erebi IP, Adaobi EC. Protective potential of aqueous leaf extract of Vernonia amygdalina in cyclophosphamide - induced myelotoxicity. IOSR J Pharm. 2014:4(3):06-14

31. Yedjou CG, Izevbigie EB, Tchounwou PB. Vernonia amygdalina-induced growth arrest and apoptosis of breast cancer (MCF-7) cells. Pharmacol Pharm. 2013;4(1):93-9.

32. Yusuf $A B$, Umar IA, Nok AJ. Effects of methanol extract of Vernonia amygdalina leaf on survival and some biochemical parameters in acute Trypanosoma brucei infection. Afr J Biochem Res. 2012:6(12):150-8.

33. Oboh FOJ, Enobhayisobo El. Effect of aqueous extract of Vernonia amygdalina leaves on plasma lipids of hyperlipidaemic adult male albino New Zealand rabbits. Afr Sci. 2009;10(4)

34. Andrew Niles MS, Tracy Worzella MS, Michael Scurria BS, Pam Guthmiller BS, Brian M, Kay Rashka BS, Deborah Lange BS, Terry LR. Multiplexed viability, cytotoxicity and apoptosis assays for cell-based screening. Cell Notes. 2006;16:12-5.

35. Tice RR, Agurell E, Anderson D, Burlinson B, Hartmann A, Kobayashi H, Miyamae Y, Rojas E, Ryu JC, Sasaki YF. Single cell gel/comet assay: guidelines for in vitro and in vivo genetic toxicology testing. Environ $\mathrm{Mol}$ Mutagen. 2000;35:206-21.

36. Singh NP, McCoy MT, Tice RR, Schneider EL. A simple technique for quantification of low levels of DNA damage in individual cells. Exp Cell Res. 1988;175:184-91.

37. Paul S, Chakraborty S, Mukherjee A, Kundu R. Evaluation of cytotoxicity and DNA damaging activity of three plant extracts on cervical cancer cell lines. Int J Pharm Sci Rev Res. 2015:31(1):183-9.

38. Demma J, Engidawork E, Hellman B. Potential genotoxicity of plant extracts used in Ethiopian traditional medicine. J Ethnopharmacol. 2009:122:136-42.

39. Kahaliw W, Aseffa A, Abebe M, Teferi M, Engidawork E. Evaluation of the antimycobacterial activity of crude extracts and solvent fractions of selected Ethiopian medicinal plants. BMC Complement Altern Med. 2017;17:143. 